The contributors are as follows :-Ask, Berg, Boström, Dalén, Ehlers, Enroth, Frieberg, Grönholm, Hagen, Holm, Höeg, Nordenson, Ploman, Rönne, Vannas, representing all three Scandinavian countries.

The editors have exercised great care that there has been no unnecessary overlapping of subjects and reiteration of ideas.

There is a very complete index of subjects, also an index of the chief authors referred to.

The binding, paper and type are all first class. The illustrations, many of them in colour, are as good as in most other leading text-books, but the iris colouring is decidedly Nordic blue. Two illustrations may be specially mentioned: one presents coloured plates of five degrees of choroidal atrophy as seen by the ophthalmoscope arranged in a vertical series, with a corresponding series of microscopic sections; another shows the various types of glaucomatous fields, and is most informative for the student.

The last three chapters deal with Accidents, Blindness, and a History of Ophthalmology respectively.

\title{
OBITUARY
}

\section{ADOLPH BRONNER}

Dr. BRONNer, whose death occurred at Bradford on February $i$, was one of the best known provincial members of the ophthalmic circle in this country in the closing years of last century and the early years of the present. Of German extraction, he was the son of Edward Bronner, M.D., of Bradford, who took a prominent part in founding the Royal Eye and Ear Hospital of that city. Born in $\mathbf{1 8 6 0}$ he was educated at Bradford and the University of London. He spent a good deal of time abroad at German Universities and qualified M.D. at Heidelberg in 1884. On his return he became a clinical assistant at Moorfields and took the M.R.C.S.(Eng.) in 1885, before settling in his native city.

Bronner succeeded his father as surgeon to the Bradford Eye and Ear Hospital in 1886. The combination of ophthalmology and laryngology in one person was not uncommon 50 years ago, and Bronner combined the work at Bradford, for he became Laryngologist at the Bradford Royal Infirmary.

Bronner was a most popular consultant in the north. He was at one time president of the Bradford Medico-Chirurgical Society ; and he was also president of the Leeds Medico-Chirurgical Society. 
On retiring from practice Bronner was elected Consulting Surgeon to the two hospitals he had served so well; while his memory is enshrined in the Bradford Eye and Ear Hospital by a tablet, placed beneath that in memory of his father.

Of his work for laryngology this is not the place to say more than that he was secretary of the section of laryngology at the International Medical Congress at Rome in 1894.

Bronner joined the Ophthalmological Society of the United Kingdom in 1886 and served on the Council for a period of three years, early in the present century. He contributed many papers of clinical importance to the Transactions and frequently joined in discussions. The subjects of these papers covered a wide range in ophthalmic medicine and surgery.

\section{NOTES}

Lectures at Moorfields Eye Hospital

A COURSE of eight lectures on modern ophthalmic instruments is to be given by Mr. E. F. Fincham, F.Inst.P., at Moorfields Eye Hospital on certain Wednesdays in April, May and June, 1936.

Details will be found in our advertisement columns this month.

Death

a

As we go to press we learn with deep regret of the death on March 12, of Dr. W. H. Wilmer of Washington. We hope to publish memoir in a later number.

\section{FUTURE ARRANGEMENTS}

\section{6}

April 2-4.-Ophthalmological Society of the United Kingdom (Annual Congress), in London.

April 3.-Midland Ophthalmological Society, at Nottingham Eye Infirmary.

May 22.- Midland Ophthalmological Society, at Addenbroke's Hospital, Cambridge.

June 12.-Royal Society of Medicine, Section of Ophthalmology (Annual Meeting).

October 6.-Midland Ophthalmological Society, at Birmingham Eye Hospital.

December 1.-Midland Ophthalmological Society, at Birmingham Eye Hospital. 